\title{
The effect of ambient air pollution on respiratory health of school
} children: a panel study Michael J Epton*1, Robin D Dawson ${ }^{1}$, Wendy M Brooks' ${ }^{1}$, Simon Kingham², Teresa Aberkane ${ }^{3}$, Jo-Anne E Cavanagh ${ }^{4}$, Christopher M Frampton ${ }^{1}$, Tracey Hewitt ${ }^{1}$, Julie M Cook ${ }^{1}$, Susan McLeod ${ }^{1}$, Fiona McCartin ${ }^{1}$, Katherine Trought ${ }^{4}$ and Leslie Brown ${ }^{4}$

\author{
Address: ${ }^{1}$ Canterbury Respiratory Research Group, Department of Medicine, Christchurch School of Medicine and Health Sciences, University o \\ Otago, PO Box 4345, Christchurch 8140, New Zealand, ${ }^{2}$ Department of Geography, University of Canterbury, Private Bag 4800, Christchurch \\ 8020, New Zealand, ${ }^{3}$ Environment Canterbury, 58 Kilmore Street, Christchurch, New Zealand and ${ }^{4}$ Landcare Research, P O Box 40, Lincoln 7640 , \\ Christchurch, New Zealand \\ Email: Michael J Epton* - michael.epton@chmeds.ac.nz; Robin D Dawson - robindawson@clear.net.nz; \\ Wendy M Brooks - bmwendyuk@yahoo.co.uk; Simon Kingham - simon.kingham@canterbury.ac.nz; \\ Teresa Aberkane - Teresa.Aberkane@ecan.govt.nz; Jo-Anne E Cavanagh - CavanaghJ@landcareresearch.co.nz; \\ Christopher M Frampton - chris.frampton@chmeds.ac.nz; Tracey Hewitt - tracey.hewitt@hotmail.com; \\ Julie M Cook - julie.cook@chmeds.ac.nz; Susan McLeod - Sue.McLeod@cdhb.govt.nz; Fiona McCartin - fiona.mccartin@chmeds.ac.nz; \\ Katherine Trought - troughtk@landcareresearch.co.nz; Leslie Brown - brownlx@landcareresearch.co.nz \\ * Corresponding author
}

Published: I4 May 2008

Environmental Health 2008, 7:16 doi:10.1186/1476-069X-7-16
Received: 28 February 2007

Accepted: 14 May 2008

This article is available from: http://www.ehjournal.net/content/7/1/16

(C) 2008 Epton et al; licensee BioMed Central Ltd.

This is an Open Access article distributed under the terms of the Creative Commons Attribution License (http://creativecommons.org/licenses/by/2.0), which permits unrestricted use, distribution, and reproduction in any medium, provided the original work is properly cited.

\begin{abstract}
Background: Adverse respiratory effects of particulate air pollution have been identified by epidemiological studies. We aimed to examine the health effects of ambient particulate air pollution from wood burning on school-age students in Christchurch, New Zealand, and to explore the utility of urine and exhaled breath condensate biomarkers of exposure in this population.
\end{abstract}

Methods: A panel study of 93 male students ( 26 with asthma) living in the boarding house of a metropolitan school was undertaken in the winter of 2004 . Indoor and outdoor pollution data was continuously monitored. Longitudinal assessment of lung function ( $F E V_{1}$ and peak flow) and symptoms were undertaken, with event studies of high pollution on biomarkers of exposure (urinary I-hydroxypyrene) and effect (exhaled breath condensate (EBC) $\mathrm{pH}$ and hydrogen peroxide concentration).

Results: Peak levels of air pollution were associated with small but statistically significant effects on lung function in the asthmatic students, but not healthy students. No significant effect of pollution could be seen either on airway inflammation and oxidative stress either in healthy students or students with asthma. Minor increases in respiratory symptoms were associated with high pollution exposure. Urinary I-hydroxypyrene levels were raised in association with pollution events by comparison with low pollution control days.

Conclusion: There is no significant effect of ambient wood-smoke particulate air pollution on lung function of healthy school-aged students, but a small effect on respiratory symptoms. Asthmatic students show small effects of peak pollution levels on lung function. Urinary I-hydroxypyrene 
shows potential as a biomarker of exposure to wood smoke in this population; however measurement of EBC $\mathrm{pH}$ and hydrogen peroxide appears not to be useful for assessment of population health effects of air pollution.

Some of the data presented in this paper has previously been published in Kingham and co-workers Atmospheric Environment, 2006 Jan; 40: 338-347 (details of pollution exposure), and Cavanagh and co-workers Sci Total Environ. 2007 Mar I;374(I):5 I-9 (urine hydroxypyrene data).

\section{Background}

Epidemiological studies have established the adverse health effects of particulate air pollution, particularly in relation to cardiac and respiratory effects $[1,2]$. However, direct assessment of health impacts of air pollution on individuals presents significant challenges, including the difficulty and expense of accurately assessing personal exposures [3,4], variation in exposure in home versus school/work and outdoor versus indoor environments and exposure to tobacco smoke. The source of the particulate pollution may also be relevant. The majority of research from the USA and Europe has studied particulate pollution from coal-fired power stations, heavy industry, and diesel engines. However, wood and other organic matter combustion may be significant source of exposure in areas burning solid fuel for domestic heating, such as Canada and the North West USA, Scandinavia, and New Zealand. Indeed there is an increasing trend for wood to be used as a source of home heating in the New England states and in upstate New York.

Direct assessment of lung effects has generally been limited to measurement of peak expiratory flow rate (PEFR) diaries, which, like any self-administered test involving writing down numerical values, may be prone to subjective bias, end-digit preference and auto-correlation. More recently, the availability of electronic downloadable spirometers means detailed lung function assessment in large cohorts can be undertaken easily and cheaply. The spirometers incorporate quality assessment protocols and provide a more objective assessment of lung function. In addition, techniques such as exhaled breath condensate collection now allow non-invasive assessment of airway inflammation, and potentially provide information about oxidative stress responses in the lungs.

The aim of this study was to examine the health effects of ambient particulate air pollution (largely derived from wood-burning for home heating) on school-age children in a panel study design, and to explore the utility of urine and exhaled breath condensate biomarkers of exposure in this population. To reduce exposure variation, and provide accurate assessment of exposure, school children from the boarding houses of a metropolitan private school were studied. Longitudinal studies of lung function effects were undertaken using personal electronic spirometers and symptom diaries, and, after high pollution events, detailed event studies of pollution effects were undertaken using exhaled breath condensate and urine collection.

Some of the data presented in this paper has previously been published in Kingham and co-workers (details of pollution exposure) [5] and Cavanagh and co-workers (urine hydroxypyrene data) [6]

\section{Methods \\ Study site}

The study was undertaken in winter 2004 in Christchurch, New Zealand, a city of 330,000 situated on the east coast of the South Island. Significant air pollution in Christchurch almost invariably occurs in winter, and is characterized by $\mathrm{PM}_{10}, \sim 90 \%$ of which is $\mathrm{PM}_{2.5}$, that is largely generated by domestic wood-burning open fires and enclosed wood-burners [7]. Mean daily $\mathrm{PM}_{10}$ in central and suburban Christchurch exceeds $50 \mu \mathrm{g} / \mathrm{m}^{3}$ on 30 days per year and can reach up to $250 \mu \mathrm{g} / \mathrm{m}^{3}$ [8]. The health effects of Christchurch air pollution have been the subject of a number of local studies [9-11].

The study was undertaken in the boarding houses at Christ's College, a single-sex private school situated in the central city, but inset into the grounds of Hagley Park, a five $\mathrm{km}^{2}$ area of grassland and trees to the immediate west of the CBD but surrounded by the urban area on all sides.

\section{Pollution monitoring}

Two pollution monitoring sites were established for this project. The indoor site was a second floor corridor leading to rooms occupied by boarding students. The building is naturally ventilated and is heated by a thermostatically controlled central heating system. The site was not near any obvious indoor sources of particulates such as kitchens which are located in a different building. The outdoor site was a courtyard within the school grounds. Indoor and outdoor particulate pollution levels $\left(\mathrm{PM}_{10}, \mathrm{PM}_{2.5}\right.$, $\mathrm{PM}_{1}$ ) were measured continuously using a TEOM Series 1400a Ambient Particulate Monitor, and expressed as 10 minute averages over a 24 hour period, and 24 hour averages, from midday to midday. It has been shown that this TEOM under-reads the true $\mathrm{PM}_{10}$ mass because of the loss of semi-volatile compounds in the heated air stream. 
Consequently the figures were corrected based on an established factor. Details about this and the more information about the indoor and outdoor pollution monitoring at Christ's College are given in Kingham and coworkers [5]. Weather data including wind speed, temperature, temperature difference and relative humidity were also continuously collected from the outdoor site and expressed as 10 minute averages.

\section{Participants}

The participants were male secondary school students, aged between 12 and 18 years, attending the boarding houses of Christ's College. All were healthy non-smokers with no significant medical conditions. Smokers were specifically requested not to volunteer for the study, and the non-smoking status of the participants was confirmed by school staff. A sub-group of students with a previous diagnosis of asthma (defined as "doctor diagnosed asthma ever") were also studied. They were being treated with asrequired short-acting beta agonist reliever medication, with some taking regular inhaled corticosteroids (see Results section for details). The regular use of oral corticosteroids was an exclusion criterion. Investigators made no alterations to asthma management and gave no advice about reliever inhaler use during the study.

Prior to commencing the study the health status of the students was assessed by taking a brief medical history. Baseline spirometry and skin prick testing for atopic status were also undertaken.

The study protocol and conduct was approved by the Canterbury Regional Ethics committee. All participants provided written informed consent prior to commencement, and parental approval to participate was also sought.

\section{Lung function assessment}

All students were issued with personal downloadable electronic spirometers (Piko-1, Ferraris Respiratory Europe Ltd, Hertford, UK) and trained in their use. These spirometers measure Forced Expiratory Volume in 1 second $\left(\mathrm{FEV}_{1}\right)$ and peak expiratory flow rate (PEFR) to American Thoracic Society standards [12]. Lung function measurement was undertaken twice daily, in the early morning, and around $6.00 \mathrm{pm}$, supervised by House Matrons, who were all trained nurses given training in spirometry. No specific instructions about withholding reliever medications prior to spirometry were given to the students. Spirometry data were downloaded at least fortnightly by investigators.

\section{Diary cards}

All students were issued with daily diary cards to detail respiratory, nasal and eye symptoms. In addition, stu- dents with asthma completed diaries detailing asthma symptoms and reliever medication use.

Lung function and diary card data collection occurred during school terms for the duration of the project. When a student was away from the school for more than one night (weekend and school holidays), diaries and lung function measurements were not undertaken.

\section{High pollution peak assessment}

Within 24 hours of two separate high pollution days all participating students underwent a more detailed assessment. The investigators were informed by Environment Canterbury the morning after a high pollution night. The school was contacted, and all participating boys were excused their evening study activities, to be assessed by the investigating team. This involved collection of urine samples for analysis of 1-hydroxypyrene and collection of exhaled breath condensate for measurement of $\mathrm{pH}$ and hydrogen peroxide. Baseline assessments were also undertaken at the beginning of the study during a period of low pollution (autumn control) and during the winter, after a 1 week period of low pollution levels (winter control).

\section{Urinary I-hydroxypyrene levels (I-OHP)}

Urine samples were stored at $-20^{\circ} \mathrm{C}$ until analysis. Urinary 1-OHP was quantified using reverse phase high-performance liquid chromatography (HPLC) using a modification of a previously described method [13] as described in Cavanagh and co-workers [6]. The lower limit of detection was $0.23 \mathrm{nmol} / \mathrm{L}$. Hydroxypyrene concentrations were corrected for urinary creatinine to account for hydration status and expressed as $\mu \mathrm{mol} 1-\mathrm{OHP} / \mathrm{mol}$ creatinine.

\section{Exhaled breath condensate (EBC) collection}

Exhaled breath condensate (EBC) was collected using the RTube $^{\mathrm{TM}}$ system (Respiratory Research Inc, Charlottesville, USA), using an aluminium cooling tube. The aluminium cooling tube was stored at $-20^{\circ} \mathrm{C}$ for at least 24 hours prior to collection. EBC was collected for ten minutes on each sampling occasion, after rinsing the mouth to reduce saliva contamination. Approximately $2 \mathrm{ml}$ of condensate was collected from each student at each collection.

\section{$E B C p H$}

EBC $\mathrm{pH}$ was immediately measured by applying approximately $30 \mu \mathrm{l}$ of EBC to a pre-calibrated Shindengen ISFET pH meter (model KS701). EBC was not de-gassed prior to pH measurement.

\section{EBC hydrogen peroxide}

$\mathrm{H}_{2} \mathrm{O}_{2}$ was measured in EBC samples using fluorometry with 4-hydroxyphenylacetic acid [14]. Briefly, following the $\mathrm{H}_{2} \mathrm{O}_{2}$-dependent conversion of 4-HPAA to the dimer 2,2'-dihydroxybiphenyl-5,5'-diacetate, the fluorescence of 
each sample was quantified within four hours using a Hitachi F4500 Fluorescence Spectrophotometer (excitation $295 \mathrm{~nm}$, emission $405 \mathrm{~nm}$; slit width $5 \mathrm{~nm}$ ex/10 nm em; PMT voltage $700 \mathrm{~V}$ ). Linear regression analysis allowed the estimation of the concentration of $\mathrm{H}_{2} \mathrm{O}_{2}$ in samples based upon a corresponding standard curve. More details of the $\mathrm{H}_{2} \mathrm{O}_{2}$ assay as used in our laboratory, including validation and optimisation can be found in Brooks and co-workers [15]. The limit of detection of the assay used for these experiments was $3.4 \mathrm{nM} \mathrm{H}_{2} \mathrm{O}_{2}$.

\section{Statistics and sample size}

For seasonal and event data comparisons of EBC $\mathrm{pH}$, hydrogen peroxide, and 1-OHP concentrations were compared using the non-parametric Friedman's test and Wilcoxon-signed rank tests as appropriate to allow for repeated observations on individuals and due to the extreme non-normality of these measures. Readings below the limit of detection for any assay were arbitrarily assigned a value corresponding to $50 \%$ of the limit of detection to avoid division by zero in any subsequent calculation. Longitudinal data was cleaned to exclude spurious or physiologically impossible data points by an $a$ priori defined protocol. Peak flow and $\mathrm{FEV}_{1}$ data for each student was expressed as a Z-score relative to the student's mean score over the period of the study. Longitudinal data analysis exploring bivariate association between lung function (Z-scores of PEFR or FEV ${ }_{1}$ ) or symptom data and pooled air pollution measures (both indoor and outdoor) and climate related measures were conducted using the non-parametric Spearman's correlation coefficient. The air pollution measures were lagged daily out to seven days and correlated with lung function and symptom scores. In this manner the potential for any lagged effect of air pollution on these measures was analysed. Variables showing some association $(\mathrm{p}<0.15)$ with lung function or symptom data from these analyses were then entered into a mixed-model linear regression analysis which included the daily use of a reliever as a covariate to confirm the independent association with lung function or symptoms. These analyses were undertaken for the dataset as a whole and repeated separately for asthmatic and non-asthmatic students.

In addition, mean levels of each of the longitudinal outcome variables for each student were calculated within moderate/high ( 24 hour average $>20 \mu \mathrm{m} / \mathrm{m}^{3}$ outdoor) pollution days and low pollution days. These levels were compared using Mann-Whitney U tests. Longitudinal data analysis exploring bivariate association between lung function (Z-scores of PEFR or FEV ${ }_{1}$ ) and pooled air pollution measures on moderate/high pollution (24 hour average $>20 \mu \mathrm{m} / \mathrm{m}^{3}$ outdoor) days alone were then conducted using the non-parametric Spearman's correlation coefficient.
The power of the study was of necessity dependant on the number and magnitude of high pollution days during the study period. In addition, limiting the sampling to one school (to increase exposure validity) placed limitations on potential numbers of students willing/able to participate. Retrospective power analysis was therefore undertaken for lung function scores (expressed as Z-scores) between moderate/high ( 24 hour average $>20 \mu \mathrm{m} / \mathrm{m}^{3}$ outdoor) pollution days and low pollution days. Assuming a 2:1 split in air pollution days, and given $\mathrm{n}=80$ students, the study had an $80 \%$ power to detect differences in $\mathrm{Z}$ score values of 0.30 in $\mathrm{FEV}_{1}$ and 0.27 in PEFR with $\alpha=$ 0.05 (two-tailed). In addition, with 100 time points a correlation between Z-scores and pollution of $>0.28$ would have been detected as statistically significant i.e. $\mathrm{R}^{2}>10 \%$.

\section{Results \\ Students' baseline demographics and lung function}

A total of 93 students took part in the study, from a total potential boarding house population of 240 students. Eighty-nine students identified themselves as New Zealand European, whilst four (4.3\%) came from Asia. There were no students who identified themselves as Maori. In $2001,6.9 \%$ of the population of Christchurch identified themselves as Maori, while 5.5\% identified themselves as Asian [16]. Twenty-six (28\%) of the students had a doctor diagnosis of asthma. The prevalence of asthma in this age group in New Zealand is $24.4 \%$ [17]. Seventeen of these students used short-acting beta agonists on an as-required basis, while eight students were taking regular inhaler corticosteroids. Mean age of the students at study start was 14 years 5 months (range 12 years 9 months - 17 years 6 months). There were no significant age differences between students with asthma and those without asthma. There was no significant difference in \% predicted $\mathrm{FEV}_{1}$ between asthmatics and non-asthmatics $(97.54 \% \pm 2.481$ (mean \pm 1 s.e.) $\mathrm{n}=26$, vs $95.49 \% \pm 1.635 \mathrm{n}=57$ ), though $\mathrm{FEV}_{1} / \mathrm{FVC}$ ratio was significantly lower in the asthmatic students $\left(\mathrm{FEV}_{1} / \mathrm{FVC}\right.$ ratio asthma group $0.803 \pm 0.013 \mathrm{n}=$ 26 vs normal group $0.834 \pm 0.009 \mathrm{n}=57, \mathrm{p}=0.05$ ).

\section{Asthmatic reliever use}

Reliever use in the asthmatic students was generally low. Reliever use was only documented on $3.26 \%$ of the days in the diary cards filled in by the asthmatic students. There was no significant difference between the number of puffs of reliever used by the asthmatics on low pollution days when compared to moderate/high days (Mann-Whitney $\mathrm{U}, \mathrm{p}=0.488$ ). There was however a relationship between days of ANY reliever use and the occurrence of a moderate/high pollution day. For this reason, the daily use of a reliever was used as a covariate in the mixed-model linear regression analysis. 


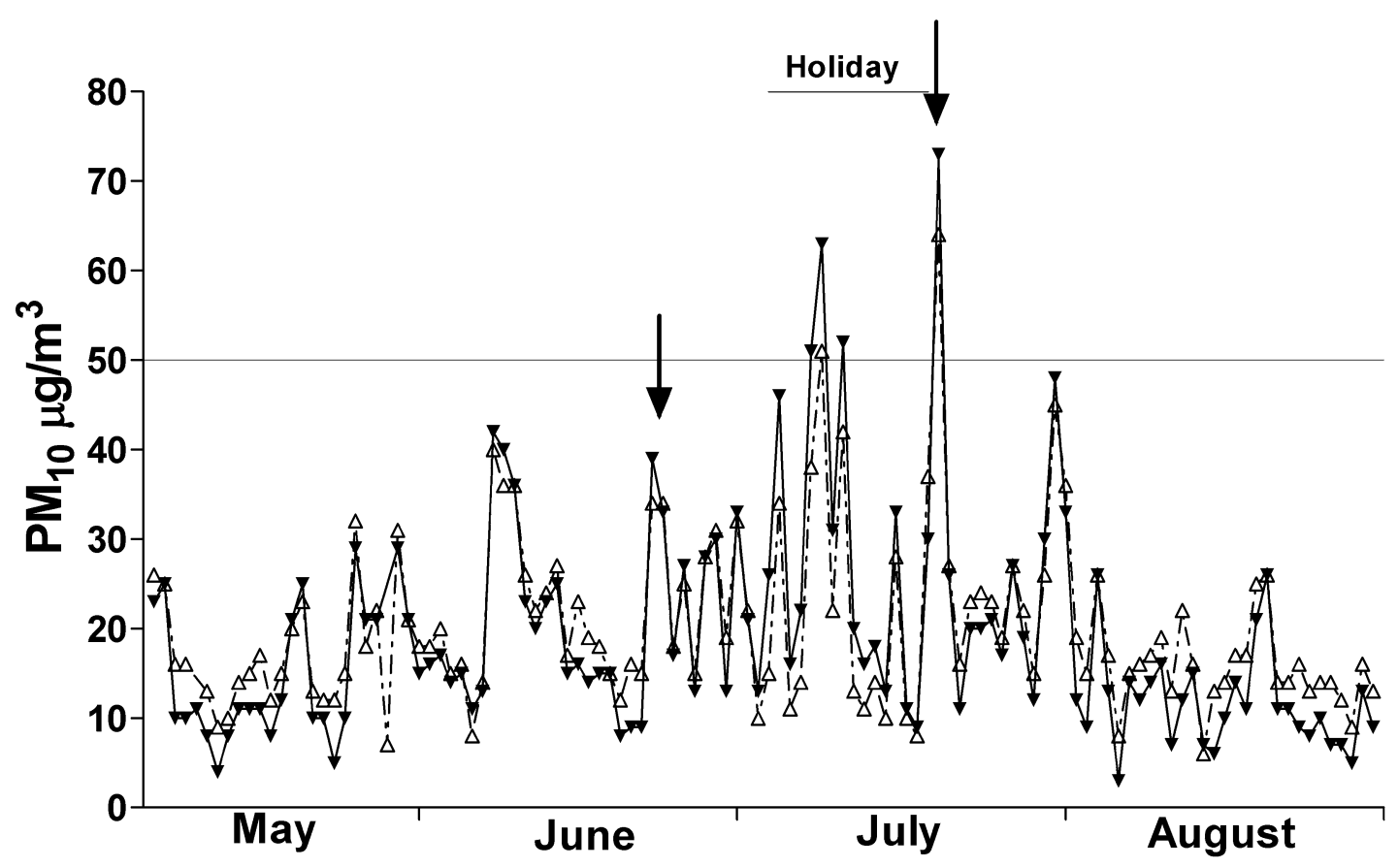

Figure I

Indoor (open triangle) and outdoor (closed triangle) 24 hour mean PM 10 levels. The school holiday period, when no biological data was collected, is marked. Detailed event studies occurred after high pollution nights marked with arrows. The New Zealand National Environmental Standard cut-off for high pollution days is marked at $50 \mu g / \mathrm{m}^{3}$. Details of monitoring sites and positions are given in the Methods section.

\section{Air pollution}

The study was undertaken from the end of March to early September 2004, encompassing autumn and winter. Indoor and outdoor pollution levels are shown in Figure 1 (24 hour average) and Figure 2 (10-min peak). Pollution levels during the winter of 2004 were generally lower than previous years [18], with the majority of high pollution nights occurring during the school vacation period, when data was not being collected. There were however a number of high pollution events where data was collected. Detailed sampling took place after high pollution nights on June 24 and July 21. The 24-hour average outside $\mathrm{PM}_{10}$ level recorded at the school on those dates was $43 \mu \mathrm{g} / \mathrm{m}^{3}$ and $72 \mu \mathrm{g} / \mathrm{m}^{3}$ respectively. Peak outdoor $\mathrm{PM}_{10}$ levels for a 10-minute period reached $105 \mu \mathrm{g} / \mathrm{m}^{3}$ and 257 $\mu \mathrm{g} / \mathrm{m}^{3}$ respectively. The majority of $\mathrm{PM}_{10}$ pollution was in the $\mathrm{PM}_{2.5}$ range, and indoor pollution levels were similar to outdoor. Occasional very high pollution peaks were identified indoors. These tended to be in the $\mathrm{PM}_{10}$ range, rather than $\mathrm{PM}_{2.5}$, and probably represented resuspension events due to activity in corridors. On average, pollution levels measured at the school were 22.5\% lower than those measured at the central Environment Canterbury monitoring station.

\section{Urinary I-OHP levels}

Urine 1-OHP levels are shown in Figure 3. Urine 1-OHP levels were significantly higher on the high pollution days compared to both low pollution control days. Median (25-75\% range, number of sample analysed) $1-\mathrm{OHP} \mathrm{lev-}$ els corrected for creatinine were: Autumn control 0.0195 (0.009-0.036, $\mathrm{n}=88) \mu \mathrm{mol} \mathrm{OHP} / \mathrm{mol}$ creatinine; Winter control $0.025(0.013-0.038, \mathrm{n}=77) \mu \mathrm{mol} \mathrm{OHP} / \mathrm{mol}$ creatinine; Pollution day $10.043(0.030-0.073, \mathrm{n}=79)$ $\mu \mathrm{mol} \mathrm{OHP} / \mathrm{mol}$ creatinine; Pollution day 20.042 (0.022$0.064, \mathrm{n}=73)$; $\mathrm{p}<0.0001$ for all comparisons of high pollution days vs controls. Differences in 1-OHP levels between the two control days did not reach statistical significance. Similarly, the 1-OHP levels on the two high pollution days were not significantly different.

\section{$E B C p H$}

EBC $\mathrm{pH}$ readings are shown in Figure 4. There was a broad range of $\mathrm{pH}$ readings on all sampling days. $\mathrm{pH}$ differences between autumn and winter controls reached statistical significance, and $\mathrm{pH}$ at the first high pollution day was significantly higher than the second study day, and the winter control day, but not the autumn control day. There 


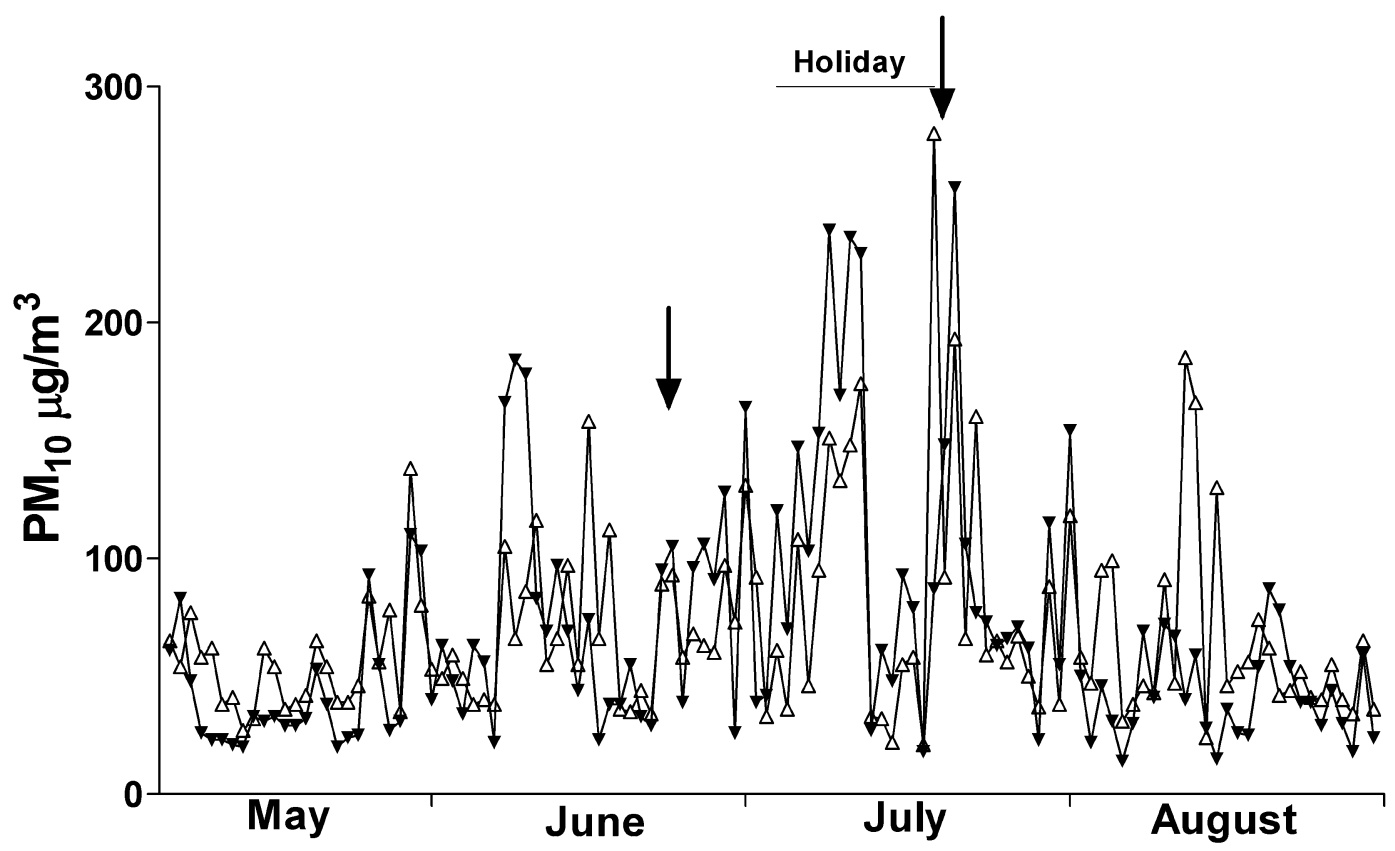

Figure 2

Indoor (open triangle) and outdoor (closed triangle) I0-minute peak $\mathbf{P M}_{10}$ levels. The school holiday period, when no biological data was collected, is marked. Detailed event studies occurred after high pollution nights marked with arrows. Details of monitoring sites and positions are given in the Methods section.

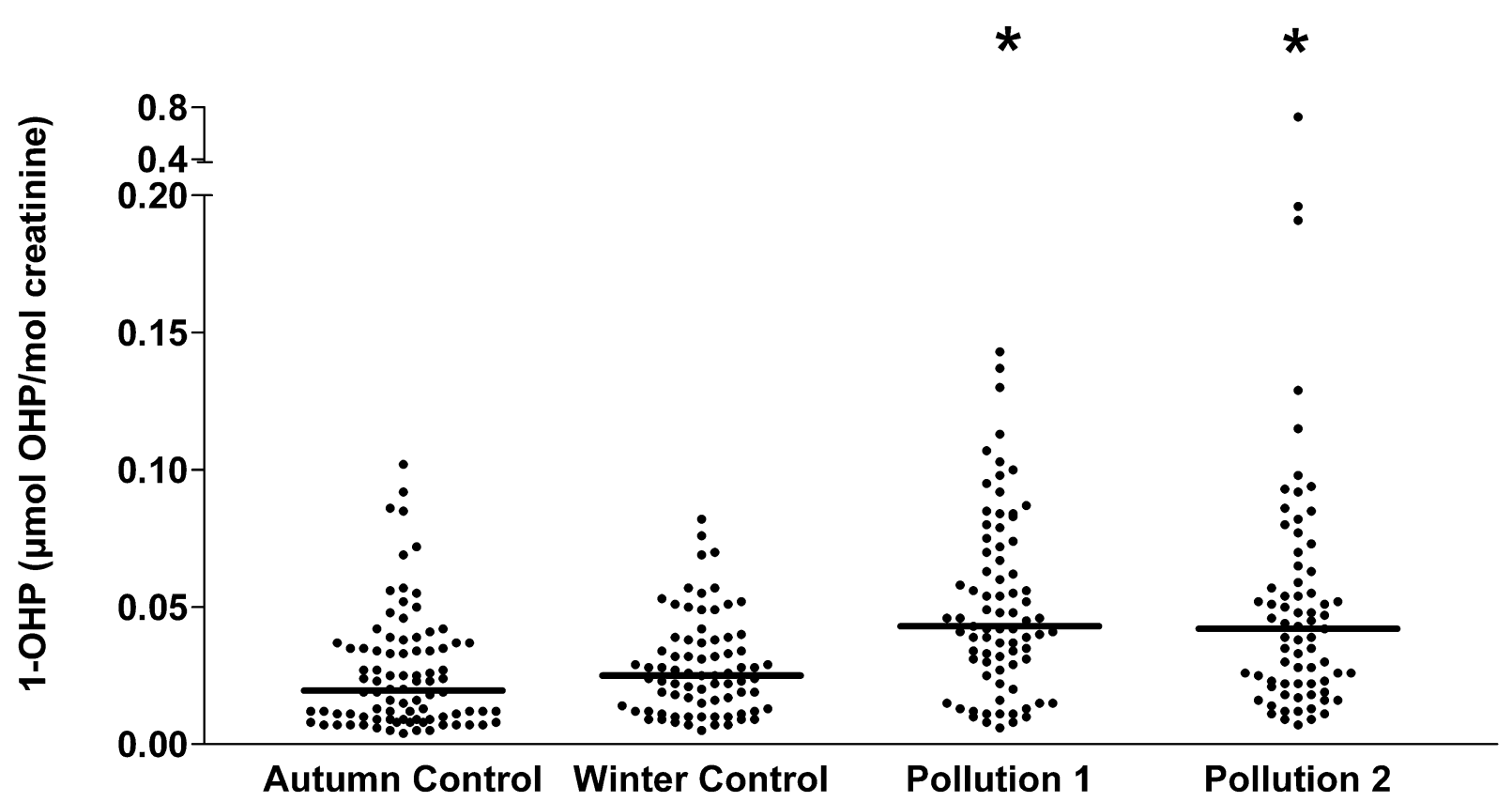

Figure 3

Urinary I-hydroxypyrene levels (adjusted for creatinine) on the control and high pollution assessment days. * $\mathrm{P}$ $<0.000 \mathrm{I}$ for all differences between high pollution days and controls. Data in this graph is also shown in graph form in Cavanagh and co-workers [6]. 


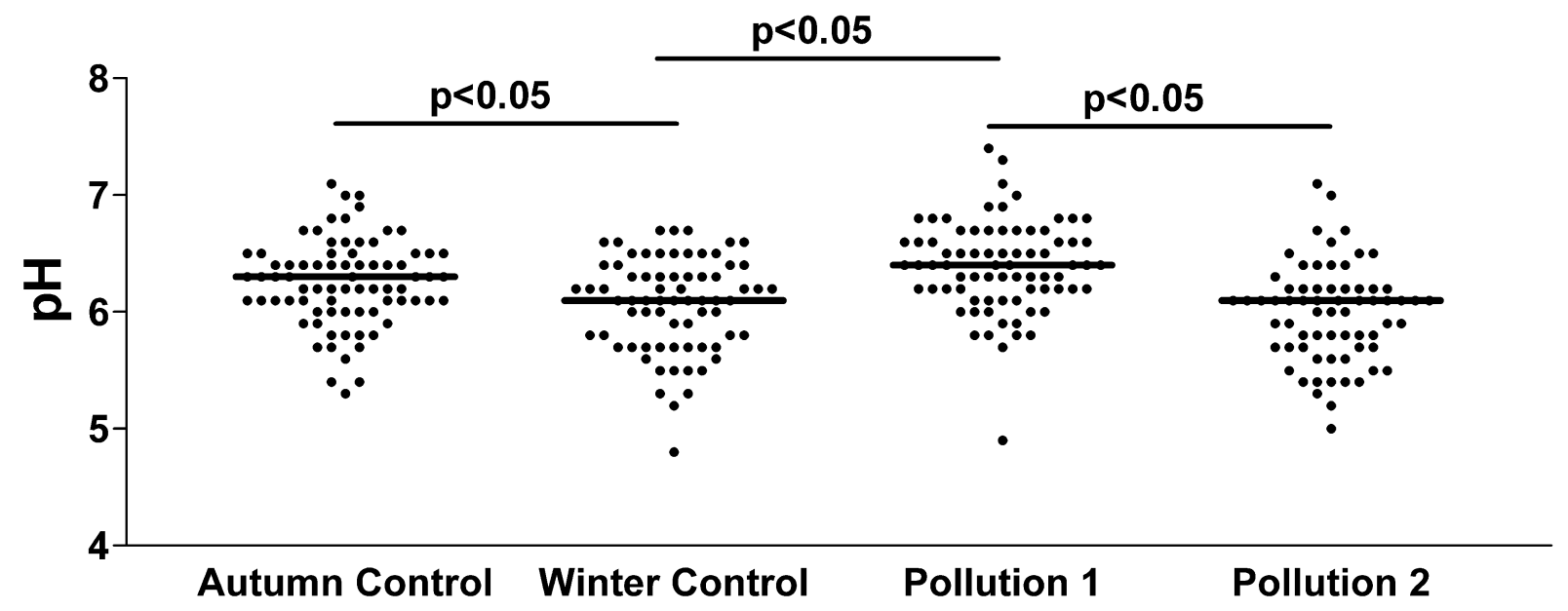

Figure 4

Exhaled breath condensate pH levels on the control and high pollution assessment days.

was no independent effect in students with asthma in comparison with healthy students.

\section{EBC hydrogen peroxide}

EBC $\mathrm{H}_{2} \mathrm{O}_{2}$ readings are shown in Figure 5. Detectable hydrogen peroxide was present in most samples. There was no difference in measured $\mathrm{H}_{2} \mathrm{O}_{2}$ between any of the sampling days, either control or high pollution. There was also no difference in proportions of samples with detectable $\mathrm{H}_{2} \mathrm{O}_{2}$. There was no independent effect of asthma in comparison with healthy subjects. There was no signifi- cant correlation between EBC levels of hydrogen peroxide, and $\mathrm{pH}$, and no correlation with either of these measurements and urinary 1-OHP.

\section{Lung function data}

$\mathrm{FEV}_{1}$ data was available for a median of 129.5 time points per student (Range 4-189). PEFR data was available for a median of 128 time points (Range 2-186). Univariate analysis identified a number of biologically plausible correlations between lung function data and $\mathrm{PM}_{10}$ levels which reached statistical significance. There was a signifi-

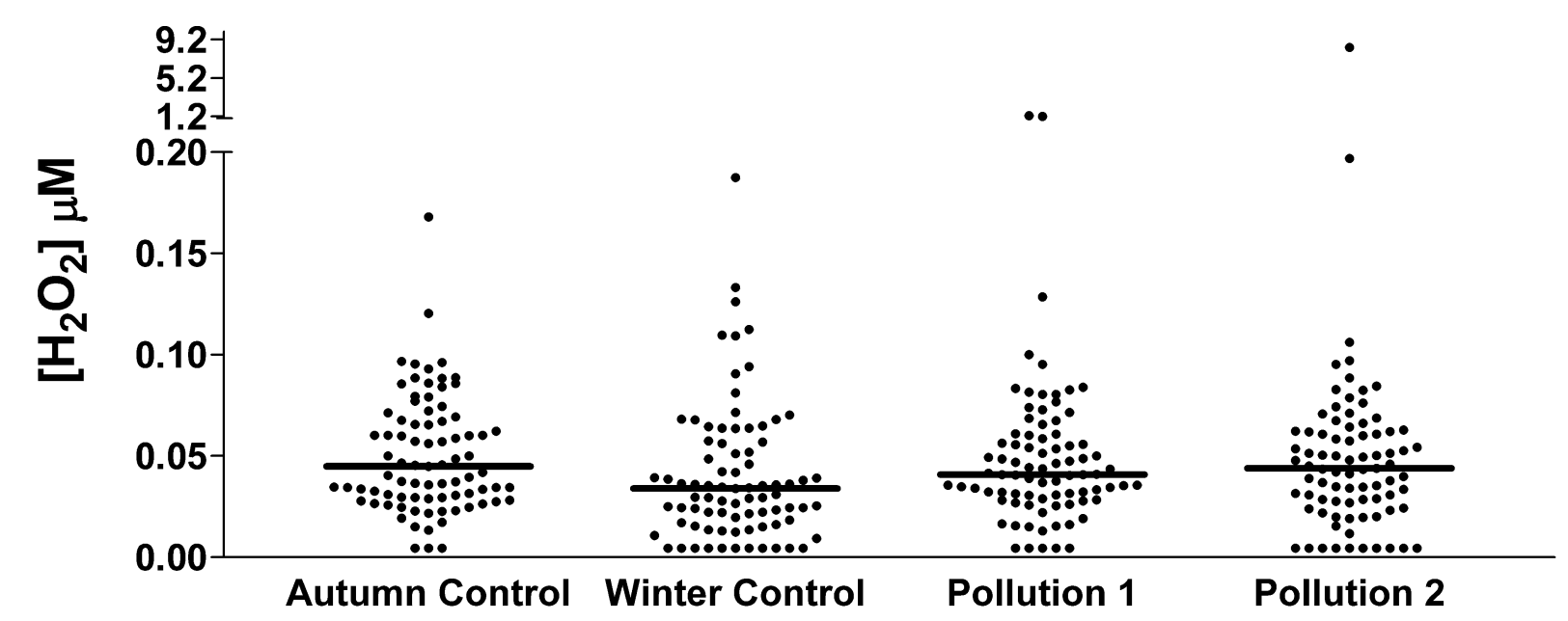

Figure 5

Exhaled breath condensate $\mathrm{H}_{2} \mathrm{O}_{2}$ levels on the control and high pollution assessment days. 
cant correlation between morning $\mathrm{FEV}_{1}$ and 24 hour average outdoor air pollution levels the previous day (Spearman's rho -0.201, $\mathrm{p}=0.034$ ). When analysing for the presence of asthma, asthmatic subjects showed correlations between $\mathrm{FEV}_{1}$ and 24 hour average outdoor air pollution levels which just failed to reach statistical significance (Spearman's rho -0.187, $\mathrm{p}=0.06$ ), while non-asthmatic subjects showed no significant correlations. There was no significant correlation between peak $\mathrm{PM}_{10}$ levels and lung function in either asthmatics or non-asthmatics. In the asthmatic subjects, there were a number of associations noted between pollution and temperature variables and the use of any reliever medication which reached statistical significance. These were daytime indoor pollution - one day lag; night-time indoor pollution - same night and one day lag; temperature; minimum and maximum inside temperature, and relative humidity. There was no significant relationship between the use of any reliever medication and any of the lung function variables in the asthmatic group.

When multivariate analysis was undertaken, using six dependent lung function variables $\left(\mathrm{FEV}_{1}\right.$ and PEF, morning and afternoon and daily variation in both measures), and lagging air pollution measures out to seven days, no pollution variable was retained in a regression model, with only minor temperature effects being retained. When asthmatics were studied separately, small but statistically significant associations between maximum outdoor air pollution levels and variability in $\mathrm{FEV}_{1}$, and night time PEFR were noted. With higher maximum out door pollution, FEV1 variability between morning and afternoon dropped, and afternoon PEFR dropped. Effect size was small, in the case of afternoon PEFR having an $\mathrm{R}^{2}$ of $3.6 \%$. Reliever use was not retained in the regression models for any of the lung function data, except for daily variability in PEF.

When comparing median morning $\mathrm{FEV}_{1}$ between moderate/high pollution days $\left(>20 \mu \mathrm{g} / \mathrm{m}^{3}\right)$ and low pollution days, students with asthma demonstrated lower readings on high pollution days $(\mathrm{p}=0.043)$. No effect was seen in non-asthmatic students. However, studying moderate/ high pollution days only, no significant correlation between lung function and pollution level could be detected, either in asthmatics or normal students.

\section{Diary card and symptom data}

Symptom score data was available for a median of 119 time points (Range 109-119). A number of biologically plausible associations were identified between symptoms and both indoor and outdoor air pollution levels. The proportion of students reporting cough and ear, nose and throat symptoms increased with increasing indoor air pollution the previous day. Maximum outdoor air pollution levels the same day were associated with increasing proportion of students reporting cough. The effect of maximum outdoor air pollution remained significant when multivariate analysis was undertaken, and remained in the model, while weather effects were excluded by the model. The effect size however was small, with a change in $\mathrm{PM}_{10}$ of $50 \mu \mathrm{g} / \mathrm{m}^{3}$ being associated with a $1.5 \%$ increase in proportions of children reporting cough (equivalent to one extra report of cough on high pollution days in this cohort). The use of reliever medication was not retained in the model when asthmatics were studied separately, and in this sub-group, the effect of maximum outdoor air pollution remained statistically significant.

\section{Discussion}

This study describes comprehensive pollution and respiratory health monitoring of a panel of students at the boarding house of a metropolitan school. Urinary 1-OHP levels were raised in association with pollution events, but no significant effect of pollution could be seen in the group as a whole either on lung function or airway inflammation and oxidative stress in healthy children. Minor increases in respiratory symptoms such as cough were associated with high pollution exposure. Children with asthma showed some small but statistically significant associations between peak levels of air pollution and lung function and symptoms, but no other significant differences in lung function or biomarkers of airway inflammation could be identified between healthy students and students with asthma.

The importance of accurate assessment of pollution exposure in health effects studies has been recognised since at least the early 1980's. The most accurate measurement tool, personal exposure monitoring, is expensive and logistically difficult, and does not easily lend itself to panel studies involving large numbers of subjects, particularly children. Differing exposures at home compared to work/school also decreases the accuracy of exposure assessment. The effect of cigarette exposure, both personal and via passive smoking, acts as a confounder for the assessment of health effects of air pollution. This study attempted to circumvent these issues by studying schoolchildren living and studying in the same, smoke-free environment. Other potential confounders such as dietary variation might also be expected to be reduced by central institutional catering. The close relationship between indoor and outdoor air pollution levels compares favourably with similar studies which have used personal exposure monitoring [19]. The difference in pollution levels measured at the school, compared with the central monitoring station argues strongly against relying solely on central monitoring for exposure assessment. 
A limitation of the approach of studying students in boarding houses of private schools is the potential for decreased generalisability of these results to the rest of the population. Students in this study were all male, predominantly identified themselves as European, and were from wealthier backgrounds than the population of Christchurch generally. It was felt, however, that the advantages of comprehensive pollution and respiratory health monitoring in this panel of non-smoking students out-weighed any potential limitations due to generalisability.

Urinary 1-hydroxypyrene has previously been proposed as a biomarker of exposure to polycyclic aromatic hydrocarbons (PAHs) [20]. Early studies primarily focussed on occupational exposure to PAHs, while recent studies have investigated environmental exposure to PAHs, including via vehicle emissions or indoor sources such as coal burning stoves and tobacco smoke $[21,22]$. The current study is the first to investigate the utility of 1-OHP for assessing environmental exposure to PAHs suggested to be primarily derived from wood-burning for home-heating. PAH concentrations are highly correlated with particulate air pollution in Christchurch [23]. The potential use of 1$\mathrm{OHP}$ as a biomarker of pollution exposure in this population is explored in more detail elsewhere [6].

Small effects of peak air pollution levels on some lung function measurements were detected in the asthmatic subjects. The effects on afternoon peak flow and decreased variability between morning and evening $\mathrm{FEV}_{1}$ might represent a 1/2-1 day lag effect of pollution on lung function in this group. Generally, the effect sizes were small. No significant independent effect of air pollution on lung function was detected in the population as a whole. It is unlikely that reliever use in the asthmatic children significantly reduced any effect size seen, since reliever use was generally very low, and the variable used for any reliever use was only retained in one model in the multivariate analysis. Even attempting to force the variable into the multivariate models did not alter the analyses. The effects in asthmatic students were only seen associated with peak pollution levels, as averaged over a 10 minute period. No association was seen between lung function and 24 hour average pollution levels in the multivariate analyses. This contrasts with the study of Trenga and co-workers who identified a relationship between 24 hour mean pollution levels and lung function in children with asthma [24].

This study also demonstrated small but statistically significant effects of pollution on ear, nose and throat symptoms in this population. This is consistent with previous studies of wood-smoke air pollution [10].

The power of the study may have been reduced by relatively low pollution levels during the winter of 2004, espe- cially during the school terms, when children were collecting lung function data. A systematic review of air pollution and panel studies in children has however suggested publication bias towards adverse effects of particulate air pollution on lung function and lower respiratory symptoms [25].

More recently, researchers have explored the utility of studying airway inflammation in the context of pollution exposure. A number of studies have recently been published describing the relationship of exhaled nitric oxide levels to pollution exposure $[26,27]$. Nitric oxide was not measured in this current study, due to the lack of portable equipment in 2004. However, exhaled breath condensate has been proposed as another simple non-invasive tool for measurement of airway inflammation [28]. Whilst nitric oxide measurement only provides information about eosinophilic airway inflammation, other markers of airway inflammation such as $\mathrm{pH}$ and hydrogen peroxide can be studied in EBC. EBC $\mathrm{pH}$ has been shown to vary between individuals and in respiratory conditions such as bronchial asthma, bronchiectasis and chronic obstructive pulmonary disease [29], and $\mathrm{EBC} \mathrm{H}_{2} \mathrm{O}_{2}$ is increased in a number of inflammatory conditions such as asthma, chronic obstructive pulmonary disease and community acquired pneumonia [30-33]. Measurement of such "biomarkers of effect" in EBC has been proposed as a way of exploring health effects of air pollution in exposed populations [24].

No demonstrable effect of pollution on EBC $\mathrm{pH}$ or $\mathrm{H}_{2} \mathrm{O}_{2}$ was demonstrated in this study, either in healthy children, or children with asthma. The ranges of results for both tests were broad, with no correlations between EBC levels of hydrogen peroxide, and $\mathrm{pH}$, and no correlation with either of these measurements and urine 1-OHP.

Similar issues are described by Doniec and co-workers who studied effects of passive smoking on $\mathrm{EBC} \mathrm{H}_{2} \mathrm{O}_{2}$ in 9 year old children [34]. They were unable to demonstrate a difference in EBC $\mathrm{H}_{2} \mathrm{O}_{2}$ between exposed and nonexposed children, though commented that low sensitivity of the assay, and wide spread of measured concentrations of $\mathrm{H}_{2} \mathrm{O}_{2}$ might mask subtle effects on airway inflammation. Similarly, Barregard and co-workers, though they describe statistically significant alterations in EBC malondialdehyde (another proposed biomarker of oxidative stress) after exposure to wood smoke, suggest that the results be interpreted with caution due to very low overall levels in EBC, with many measurements below detection limit of the assay [35]. Assay variability when measuring $\mathrm{H}_{2} \mathrm{O}_{2}$ using fluorimetry and colorimetry is broad in the reported literature, with some studies reporting good agreement of results [36-38], while others show higher coefficients of variation $[32,39,40]$. 
EBS pH was measured immediately after collection, without argon degassing or standardisation for $\mathrm{CO}_{2}$ partial pressure. There continues to be vigorous debate about the merits of each of these approaches [41], however degassing is not a feasible approach when collecting and processing large numbers of samples in a short period.

The potential drawbacks of EBC analysis, including assay variability and very low biomarker concentration have been highlighted in a recent review article [42] and are addressed in the ATS/ERS taskforce position paper on EBC [43]. At this stage, EBC collection and analysis appears to show utility in highly controlled research settings, but the current collection and analysis techniques are not suitable for application "in the field" for community assessment of effects of air pollution.

\section{Conclusion}

In summary, in this study we detected no significant effect of ambient wood-smoke particulate air pollution on lung function of healthy school-aged male students, but a small effect on cough. Small but significant effects of peak pollution levels were seen in students with asthma. Urinary 1-OHP shows potential as a biomarker of exposure to PAHs in wood smoke in this population; however measurement of EBC $\mathrm{pH}$ and hydrogen peroxide using current methods of collection and analysis appears not to be useful for assessment of population health effects of air pollution.

\section{Competing interests}

The authors declare that they have no competing interests.

\section{Authors' contributions}

All authors made substantial contributions to the conception and design of the study, and the acquisition of data. All have been involved in the drafting and revision of the manuscript. All have read and approved the final manuscript. ME was principal investigator for the study, and took overall responsibility for the design, implementation and analysis of the study. SK and TA coordinated the pollution monitoring and analysis and contributed to event study assessments; JC, LB, and KT coordinated the collection and analysis of the urinary 1-OHP samples and contributed to event study assessments; RD, TH, SM, FM, and JC coordinated the diary card and spirometry data acquisition, and coordinated the event study assessments. WB undertook the EBC hydrogen peroxide analysis and contributed to event study assessments. CF was the biostatistician for the study.

\section{Acknowledgements}

This study would not have been possible without the generous help and support of the students and staff of Christ's College, Christchurch, and the support of Environment Canterbury.
The study was funded by the Health Research Council of New Zealand and was part of a larger project entitled "Health and Air Pollution in New Zealand - Christchurch Pilot Study" (HAPiNZ) funded by the Health Research Council of New Zealand, the Ministry of the Environment, and the Ministry of Transport.

\section{References}

I. Dockery DW: Epidemiologic evidence of cardiovascular effects of particulate air pollution. Environ Health Perspect 200I, I 09 Suppl 4:483-486.

2. Anonymous: Health effects of outdoor air pollution. Committee of the Environmental and Occupational Health Assembly of the American Thoracic Society. Am J Respir Crit Care Med 1996, I 53(1):3-50.

3. Janssen NA, Hoek G, Brunekreef B, Harssema H, Mensink I, Zuidhof $A$ : Personal sampling of particles in adults: relation among personal, indoor, and outdoor air concentrations. Am J Epidemiol 1998, I 47(6):537-547.

4. Janssen NA, Hoek G, Harssema H, Brunekreef B: Personal sampling of airborne particles: method performance and data quality. J Expo Anal Environ Epidemiol 1998, 8( I):37-49.

5. Kingham S, Durand M, Aberkane T, Harrison J, Wilson JG, Epton M: Winter comparison of TEOM, MiniVol and DustTrak PMIO monitors in a woodsmoke environment. Atmos Environ 2006, 40(2):338-347.

6. Cavanagh JA, Brown L, Trought K, Kingham S, Epton MJ: Elevated concentrations of I-hydroxypyrene in schoolchildren during winter in Christchurch, New Zealand. Sci Total Environ 2007, 374(I):5I-59.

7. Scott A], Gunatilaka M: Christchurch inventory of emissions to air. R04/03. Christchurch, New Zealand, Environment Canterbury; 2004.

8. Aberkane T, Harvey M, Webb M: Annual ambient air quality monitoring report 2003. U04/58. Christchurch, New Zealand, Environment Canterbury; 2004.

9. McGowan JA, Hider RN, Chacko E, Town GI: Particulate air pollution and hospital admissions in Christchurch, New Zealand. Aust N Z J Public Health 2002, 26(I):23-29.

10. Harre ES, Price PD, Ayrey RB, Toop LJ, Martin IR, Town GI: Respiratory effects of air pollution in chronic obstructive pulmonary disease: a three month prospective study. Thorax 1997, 52(1 2): 1040- 1044.

II. Hales S, Salmond C, Town GI, Kjellstrom T, Woodward A: Daily mortality in relation to weather and air pollution in Christchurch, New Zealand. Aust N Z J Public Health 2000, 24(I):89-9I.

12. Anonymous: ATS statement--Snowbird workshop on standardization of spirometry. Am Rev Respir Dis 1979, I | 9(5):831-838.

13. Hansen AM, Poulsen OM, Christensen JM, Hansen SH: Determination of I-Hydroxypyrene in Human Urine by High-Performance Liquid-Chromatography. J Anal Toxicol 1993, I 7(I):38-4I.

14. Hyslop PA, Sklar LA: A quantitative fluorimetric assay for the determination of oxidant production by polymorphonuclear leukocytes: its use in the simultaneous fluorimetric assay of cellular activation processes. Anal Biochem 1984, I 4 I (I):280-286.

15. Brooks WM, Lash H, Kettle AJ, Epton MJ: Optimising hydrogen peroxide measurement in exhaled breath condensate. Redox Rep 2006, I I(2):78-84.

16. Demographic Trends 2003 [http://www.stats.govt.nz/analyticalreports/dem-trends-03/default.htm].

17. Worldwide variation in prevalence of symptoms of asthma, allergic rhinoconjunctivitis, and atopic eczema: ISAAC. The International Study of Asthma and Allergies in Childhood (ISAAC) Steering Committee. Lancet 1998, 35 I(9I I I): I 225-I232.

18. Aberkane $\mathrm{T}$, Harvey $\mathrm{M}$, Webb $\mathrm{M}$ : Annual ambient air quality monitoring report 2004 Report No. U05/6I. Christchurch , Environment Canterbury; 2005.

19. Janssen NAH, Lanki T, Hoek G, Vallius M, de Hartog J], Van Grieken $\mathrm{R}$, Pekkanen J, Brunekreef B: Associations between ambient, personal, and indoor exposure to fine particulate matter constituents in Dutch and Finnish panels of cardiovascular patients. Occup Environ Med 2005, 62(I 2):868-877. 
20. Jongeneelen FJ, Bos RP: Excretion of Pyrene and Hydroxypyrene in Urine. Cancer Lett 1990, 5 I (2): 175-I77.

21. Siwinska E, Mielzynska D, Bubak A, Smolik E: The effect of coal stoves and environmental tobacco smoke on the level of urinary I-hydroxypyrene. Mutat Res-Gen Tox En 1999, 445(2): I 47-I53.

22. Hansen AM, Raaschou-Nielsen O, Knudsen LE: Urinary I-hydroxypyrene in children living in city and rural residences in Denmark. Sci Total Environ 2005, 347(I-3):98-I05.

23. Brown LE, Trought KR, Bailey Cl, Clemons JH: 2,3,7,8-TCDD equivalence and mutagenic activity associated with PMIO from three urban locations in New Zealand. Sci Total Environ 2005, 349(I-3): $161-174$.

24. Trenga CA, Sullivan JH, Schildcrout JS, Shepherd KP, Shapiro GG, Liu LJ, Kaufman JD, Koenig JQ: Effect of particulate air pollution on lung function in adult and pediatric subjects in a Seattle panel study. Chest 2006, I29(6): |6| 4-1622.

25. Ward DJ, Ayres JG: Particulate air pollution and panel studies in children: a systematic review. Occup Environ Med 2004, 6 I(4): 13 doi: I0.I I36/oem.2003.007088

26. Mar TF, Jansen K, Shepherd K, Lumley T, Larson TV, Koenig JQ: Exhaled nitric oxide in children with asthma and short-term PM2.5 exposure in Seattle. Environ Health Perspect 2005 I I3(I 2): 179|-1794.

27. Jansen KL, Larson TV, Koenig JQ, Mar TF, Fields C, Stewart J, Lippmann M: Associations between health effects and particulate matter and black carbon in subjects with respiratory disease. Environ Health Perspect 2005, I I3(1 2): 174I-1746.

28. Hunt J: Exhaled breath condensate: an evolving tool for noninvasive evaluation of lung disease. J Allergy Clin Immunol 2002, I I O(I):28-34

29. Kostikas K, Papatheodorou G, Ganas K, Psathakis K, Panagou P, Loukides S: $\mathbf{p H}$ in expired breath condensate of patients with inflammatory airway diseases. Am J Respir Crit Care Med 2002, 165(10): : 364- 1370

30. Horvath I, Donnelly LE, Kiss A, Kharitonov SA, Lim S, Chung KF, Barnes PJ: Combined use of exhaled hydrogen peroxide and nitric oxide in monitoring asthma. Am J Respir Crit Care Med 1998, I 58(4): 1042-1046.

3I. Dekhuiizen PN, Aben KK, Dekker I, Aarts LP, Wielders PL, van Herwaarden $C L$, Bast $A$ : Increased exhalation of hydrogen peroxide in patients with stable and unstable chronic obstructive pulmonary disease. Am J Respir Crit Care Med 1996, I54(3 Pt I):813-816.

32. van Beurden W], Dekhuijzen PN, Harff GA, Smeenk FW: Variability of exhaled hydrogen peroxide in stable COPD patients and matched healthy controls. Respiration 2002, 69(3):2II-2I6.

33. Majewska E, Kasielski M, Luczynski R, Bartosz G, Bialasiewicz P, Nowak $D$ : Elevated exhalation of hydrogen peroxide and thiobarbituric acid reactive substances in patients with community acquired pneumonia. Respir Med 2004, 98(7):669-676.

34. Doniec Z, Nowak D, Tomalak W, Pisiewicz K, Kurzawa R: Passive smoking does not increase hydrogen peroxide (H2O2) levels in exhaled breath condensate in 9-year-old healthy children. Pediatr Pulmonol 2005, 39(I):4I-45.

35. Barregard L, Sallsten G, Andersson L, Almstrand AC, Gustafson P, Andersson M, Olin AC: Experimental exposure to wood smoke: Effects on airway inflammation and oxidative stress. Occup Environ Med 2007.

36. Ho LP, Faccenda J, Innes JA, Greening AP: Expired hydrogen peroxide in breath condensate of cystic fibrosis patients. Eur Respir J 1999, I3(I): 103-106.

37. Kostikas K, Papatheodorou G, Psathakis K, Panagou P, Loukides S: Oxidative stress in expired breath condensate of patients with COPD. Chest 2003, I 24(4): / 373-1380.

38. van Beurden WJ, van den Bosch MJ, Janssen WC, Smeenk FW, Dekhuijzen PN, Harff GA: Fluorimetric analysis of hydrogen peroxide with automated measurement. Clin Lab 2003, 49(I I12):637-643

39. Schleiss MB, Holz O, Behnke M, Richter K, Magnussen H, Jorres RA The concentration of hydrogen peroxide in exhaled air depends on expiratory flow rate. Eur Respir J 2000, I6(6): III5-III8.

40. Van Hoydonck PG, Wuyts WA, Vanaudenaerde BM, Schouten EG, Dupont LJ, Temme EH: Quantitative analysis of 8-isoprostane and hydrogen peroxide in exhaled breath condensate. Eur Respir J 2004, 23(2): 189-192.

4I. Kullmann T, Barta I, Lazar Z, Szili B, Barat E, Valyon M, Kollai M, Horvath I: Exhaled breath condensate pH standardised for $\mathrm{CO} 2$ partial pressure. Eur Respir J 2007, 29(3):496-50I.

42. Barnes PJ, Chowdhury B, Kharitonov SA, Magnussen H, Page CP, Postma D, Saetta M: Pulmonary biomarkers in chronic obstructive pulmonary disease. Am J Respir Crit Care Med 2006, 174(I):6-14.

43. Horvath I, Hunt J, Barnes PJ, Alving K, Antczak A, Baraldi E, Becher G, van Beurden WJ, Corradi M, Dekhuijzen R, Dweik RA, Dwyer T, Effros R, Erzurum S, Gaston B, Gessner C, Greening A, Ho LP, Hohlfeld J, Jobsis Q, Laskowski D, Loukides S, Marlin D, Montuschi P, Olin AC, Redington AE, Reinhold P, van Rensen EL, Rubinstein I, Silkoff P, Toren K, Vass G, Vogelberg C, Wirtz H: Exhaled breath condensate: methodological recommendations and unresolved questions. Eur Respir J 2005, 26(3):523-548.

Publish with Biomed Central and every scientist can read your work free of charge

"BioMed Central will be the most significant development for disseminating the results of biomedical research in our lifetime. "

Sir Paul Nurse, Cancer Research UK

Your research papers will be:

- available free of charge to the entire biomedical community

- peer reviewed and published immediately upon acceptance

- cited in PubMed and archived on PubMed Central

- yours - you keep the copyright 